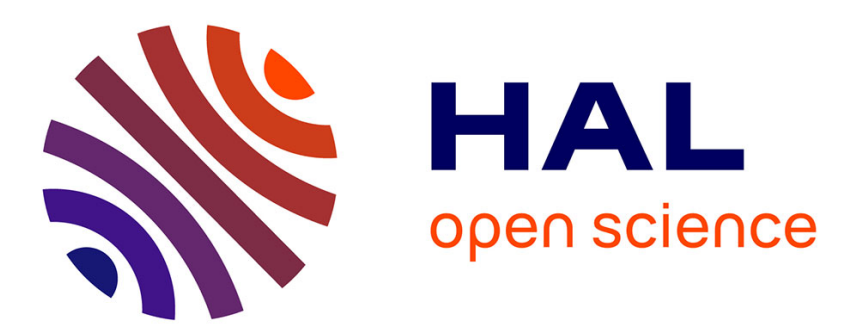

\title{
The Role of Control Systems in the Process of Change: Application to a Family Business Succession
}

\author{
Christophe Herriau, Lionel Touchais
}

\section{To cite this version:}

Christophe Herriau, Lionel Touchais. The Role of Control Systems in the Process of Change: Application to a Family Business Succession. Journal of Change Management, 2015, 15 (1), pp.19-42. 10.1080/14697017.2014.922603 . hal-03125391

\section{HAL Id: hal-03125391 \\ https://hal.science/hal-03125391}

Submitted on 29 Jan 2021

HAL is a multi-disciplinary open access archive for the deposit and dissemination of scientific research documents, whether they are published or not. The documents may come from teaching and research institutions in France or abroad, or from public or private research centers.
L'archive ouverte pluridisciplinaire HAL, est destinée au dépôt et à la diffusion de documents scientifiques de niveau recherche, publiés ou non, émanant des établissements d'enseignement et de recherche français ou étrangers, des laboratoires publics ou privés. 


\section{The Role of Control Systems in the Process of Change:}

\section{Application to a Family Business Succession}

\section{CHRISTOPHE HERRIAU \& LIONEL TOUCHAIS}

University of Rennes 1, CREM UMR CNRS 6211, France

ABSTRACT This article examines the controllable nature of organizational change. Its purpose is to provide a new reading of the process of change via the instrumentation of control that an organization can put in place. How do control systems intervene in the process of organizational transformation? How can they be used to shake up long-standing practices and justify the changes required? These research questions are answered by combining the results from the control system and organizational fields of research. This allows the authors to analyze the link between control systems and the different aspects of change: radicality, intentionality and temporality. The conceptual framework is then tested via a case study of a family business succession. This article makes several major contributions. Firstly, it shows that there is a dynamic interaction between control and change: its radicality (evolutionary revolutionary), its intentionality (built - prescribed) and its temporality (unfreezing, moving, refreezing). Furthermore, it demonstrates that control systems are able to structure a family business succession by inducing suitable behaviours. In addition, it provides an understanding of how individual and organizational learning, which are necessary in situations of change, can be initiated and tallied with control systems.

KEY WORDS: Levers of control, management of change, nature and process of change, family business succession 


\section{Introduction}

There is a large body of well-documented research on organizational change processes. However, certain authors believe that the management of change should be considered from new perspectives (Pettigrew et al., 2001; By, 2005; Palmer and Dunford, 2008; By et al., 2011). In particular, there is a need for greater acknowledgement of the connections between change management tools and techniques, and change management models (Hughes, 2007), especially regarding management control systems (Ford and Greer, 2005). Many tools are proposed to deal with change, such as communication and training activities, the creation of working groups, and identifying key actors to disseminate the change. However, the question of how control systems influence processes of change is rarely examined.

In particular, control systems are primarily approached in a traditional manner - to implement the organizational evolution previously decided upon by managers. Nevertheless, some studies show that control can also intervene in the process of change. Control systems are effective tools in the promotion and management of change (Dent, 1990; Langfield-Smith, 1997; Shields, 1997; Burns and Vaivio, 2001). They encourage employees to identify necessary evolutions, to take adapted risks, to test and to innovate (Shields, 1997). This approach does not wholly match the traditional vision of control which, rather than promoting change, seeks to establish a framework governing the actions of individuals. Otley (2001) considers that "accounting systems are often implicated in the wider processes of organizational change, providing both a vehicle through which some changes can be promoted but also a potential rigidity and barrier to change". He thus considers that "there are important connections to be made with those who study the processes of change management within organizations".

Because many family-owned business successions fail, some scholars attempt to highlight the key factors for success (Miller et al., 2003; De Massis et al., 2008). For instance, De Massis et al. (2008) show the importance of individual factors, relationships with/between 
family and nonfamily members, the financial context, and contextual items. Social control and long-term relations between family members in the context of a family succession are also well-known (Royer et al., 2008). However, it is not really known whether, and how, control systems can help in this kind of change. A review of the extant literature indicates that little systematic attention has been given to management tools such as control systems. This article therefore specifically focuses on the way in which control systems can structure the process of change in a family business transfer.

The purpose of the present article is to provide a new reading of the process of change by examining the control systems that an organization may choose to put in place, particularly in the context of a family business succession. It aims to answer certain questions raised by Burns and Vaivio (2001). In particular, these authors consider how control systems intervene in the process of organizational transformation: how do they shake up long-standing practices and justify the developments required? More generally, this issue goes back to the question of the nature and the role of the tools used to manage change.

Many scholars consider that control systems have been operationalized from a narrow focus, usually based on formal financial controls (Berry et al., 2009). For instance, to support the role of management control systems in organizational change, Kloot (1997) writes that it "is necessary to take a broad view of these systems, and not limit them to traditional budgeting and accounting systems". The present study therefore defines a control system as the set of formal and informal control mechanisms used to achieve the goals of the organization by influencing behaviours (Kloot, 1997; Bisbe and Otley, 2004; Kober et al., 2007; Ferreira and Otley 2009). In other words, the "control package" combines both "formal mechanisms, processes, systems, and networks used by organizations" and informal controls "referred to as social control and relational governance", which include "informal cultures and systems influencing members", and essentially relate to "mechanisms encouraging self-regulation" (Berry et al., 2009; Ferreira and Otley, 2009). 
To answer the research questions of the present study, the results from the control system and organizational fields of research are combined. This allows the place of control systems in situations of change to be analyzed using the characteristics of change: radicality, intentionality and temporality. This study then sets out the qualitative methodology of the research in order to test the conceptual framework using a case study of a father-to-son company succession. The results are presented and discussed by examining their effect on the conceptual model.

This article makes four major contributions. Firstly, it shows that control is not limited to the stabilization and conformation of the behaviours adopted to implement change and to control its implementation. It can also convey the desired change by building a new representation of the organization in order to facilitate the development of new behaviours and logics of action. Furthermore, control can become a tool used by all employees to manage and build change. It stimulates and frames their initiatives and their experiments, which are sources of learning and new knowledge. Secondly, this article shows that there is a dynamic interaction between control systems and change. Different levers of control can be used according to the characteristics of change: radicality (evolutionary versus revolutionary), intentionality (built versus prescribed) and temporality (unfreezing, moving, refreezing). This research proposes an analytical and operational framework linking the characteristics of change and the control tools. Thirdly, by using the model developed, it demonstrates that control systems can structure a family business succession by influencing the behaviour of organizational participants. In this way, this research attempts to fill a gap in the family business succession literature by seeking to gain an understanding of the role of control systems in such situations. Finally, beyond this dynamic perspective on control and change, this research emphasizes how individual and organizational learning, which are necessary in situations of change, can be initiated and tallied with control systems which are used not only in an exclusively instrumental way, but which may also be employed from an interactionist perspective. 


\section{The role of control in facing change}

An abundant literature treats change from at least two perspectives. One line of thought addresses the factors that influence the process of change: contextual environmental factors, organizational factors and individual factors. The second approach focuses on the design of the process of change. It is possible to identify how managerial latitude contributes to facing change, the rationality of the process, its incremental character and its rhythm. From these two points of view, control systems can fulfil different roles.

\section{Control: a brake on change or a means of conveying change}

A control system can result in a relatively simplified representation of the organization, its performance and its environment. If actors see only through this prism, their perception of reality can be strongly forced and erroneous. This does not facilitate an awareness of change and its emerging installation (Miller, 1993). A control system can also cause inertia (Dent, 1990). Indeed, for Nelson and Winter (1982), the routinized control system may be deployed so extensively that it impedes the firm's adaptation. Sometimes, the organizational behaviour is too strongly channelled by prevailing routine to be able to face change.

Nevertheless, control systems can also facilitate the adaptation of the organization to its new environments and strategies (Langfield-Smith, 1997). They allow the organization to withdraw from the existing framework by creating new images of the organization and its relationships with the environment. They change the old organizational paradigm via an unlearning process (Dent, 1990). Finally, the framework conveyed by control can help to support the emergence and installation of new strategic and organizational schemes and thus of new logics of action.

In the context of a privatization, Ogden and Anderson (1999) show that the new control system (allocated targets, new information, and the way in which they are monitored) supports the organizational change process. It plays an important teaching role by communicating the new organizational realities imposed by both privatization and managers, and ways of dealing 
with these realities. Ezzamel et al. (2004) demonstrate, in addition, that the diffusion of newlydeveloped performance measurements creates a new representation of the organization with a new common language. This facilitates the questioning of existing practices and behaviours and their replacement by a logic of action which is more in-phase with the newly adopted strategy. Chenhall and Euske (2007) also show that, under certain conditions, the control system constitutes a common language allowing a change in the thinking patterns of the organization.

\section{Control: a source of change}

A control system enables:

- Recognition of the need for change. It clarifies the degradation of the company's situation (in terms of market share, turnover, results etc.) and its environmental changes; and

- An analysis of the need for change and a contribution to the solutions required to face this change.

Nevertheless, by framing behaviours, the traditional vision of control does not facilitate the necessary upheaval for change. It does not encourage curiosity and experimentation, which are sources of innovation (Dent, 1990). It is instead synonymous with constraint and discipline. On the contrary, to promote change, the management control system should:

- Give latitude and support cooperation within the organization to enable contradictions and different points of view to be expressed; and

- Use reward systems not purely limited to the results obtained, so that creativity and risktaking are not inhibited (Kloot, 1997).

Control: a way of building and structuring change

Simons (1995) shows that companies develop a dual control system with: 
- Diagnostic control (weak involvement of operational leaders) focused on the key success factors with management by exception. The system is designed to be efficient and effective. It aims to conform and constrain rather than to develop new ideas and initiatives. It is used to frame the behaviours of the various actors, and to control them a posteriori; and

- Interactive control of strategic uncertainties with significant direct involvement of the company's headquarters, and where each person participates in frequent hierarchical and transverse exchanges. This type of control is less directive and less prescriptive. It is a source of dialogue, innovation and organizational learning.

With this dual conception of control, firms can put in place a control system synonymous with constraint and conformity as well as flexibility and innovation. Control is not merely limited to standardizing behaviour. It can also be conceived as a way of exchanging points of view, as well as of confronting knowledge and experiences. These exchanges lead to common specific solutions and also to the construction of collective procedures of interpretation and problem-solving. They support collective and individual learning.

Diagnostic control also leads to organizational learning through the corrective actions that it generates. It is simple loop learning (detection and correction of dysfunctional practices by making adjustments to such practices, but without questioning the established framework). However, double loop learning (questioning the standards structuring the activity), enabled by interactive control, is the only learning process that makes it possible to deal with important strategic changes which require the development of new organizational paradigms. In fact, management control systems and organizational learning are closely integrated. They are inextricably interwoven (Kloot, 1997). "Both diagnostic and interactive use of control systems are key components of organizational learning processes" (Ferreira and Otley, 2009).

Abernethy and Brownell (1999) show that an interactive budgetary system, which facilitates organizational learning, is better suited to situations of strategic change. In addition, Kober et al. (2007) show that the interactive use of control tools facilitates strategic evolutions which 
are accompanied afterwards by an adaptation of the control system. However, the importance of the interactivity appears to be related to the nature of strategic changes, namely whether the position of prospector or defender is taken (Naranjo-Gil and Hartmann, 2007). In other words, this result may be partially explained by a new strategy of prospector and not only by the need to manage the change. Bisbe and Otley (2004), for their part, find that interactive control reduces innovation in high-innovating companies because the discussions and negotiations probably lead to ideas being screened. Interactive control may favour innovation in lowinnovating firms only, by providing guidance for searching, triggering and stimulating initiatives.

Control can therefore become a tool used by all employees to manage and build change. It stimulates and frames their initiatives and their experiments, which are sources of learning and new knowledge. In other words, diagnostic control ensures the continuity of knowledge stabilized by capitalizing accumulated experience. By contrast, interactive control manages change by building new fundamental knowledge.

Finally, in a situation of change, control can fulfil various roles according to its methods and whether managers use it:

- As an inhibiting tool, source of inertia or, on the contrary, a tool revealing the need for change;

- As a tool conveying desired change by building a new representation of the organization in order to facilitate the development of new behaviours and logics of action;

- As a tool to structure the project of change by leading the actors to co-build its contents. It stimulates and frames initiatives as well as individual and collective experiments; or - As a tool to control behaviours and processes with respect to a strategic framework.

However, these first conclusions incorporate neither the temporality of change, nor its main features. 


\section{Control and the radicality, intentionality and temporality of change}

We analyse control processes and systems via three perspectives related to change: its radicality, its intentionality and its temporality.

\section{Radicality of change: revolutionary versus evolutionary change}

The radical aspect of change, by analogy with signal-detection theory, is characterized by its perceived degree of amplitude, its impact and its strategic importance for managers. Related to the notion of archetypes (Greenwood and Hinings, 1988), and defined as a collection of values and beliefs which manifest themselves through particular structural arrangements, radical change can be described as a transition from one organizational configuration to another "that has clear archetypal status" (Amis and Hinings, 2004). In this perspective, Simons (1994) shows that the levers of control differ according to whether the change is evolutionary or revolutionary. An important part of the literature has focused on evolutionary change (Heracleous and Barret, 2001), which shows how a gradual change inside an established framework (Jarret, 2008) becomes significant by accumulation.

Simons shows that a company has the following four levers:

- A belief system to facilitate the framing of actions around the key values of the organization, its objectives and its missions;

- Interactive control focused on strategic uncertainties allowing management to encourage and take part in the emergence of new strategies;

- Boundary systems to fix the formal and informal rules that employees must respect; and

- Diagnostic control with information feedback on critical variables of performance.

The first two levers are described as positive creative forces and sources of inspiration at the direction of, and in conformity with, the wishes of leaders. The second two levers create constraints and monitor the realization of the strategy and compliance with the rules. 
When change is perceived as being important, Simons (1994) shows that leaders revise the belief and boundary systems of their organization in order to shake up the established order (to change paradigms, to generate unlearning) and to give a new impulse (desirable ideas and initiatives) by indicating those decisions and actions that will no longer be tolerated. Afterwards, they use diagnostic control to structure and communicate performance expectations.

When change is perceived as being less important, leaders seek to make the organization critically consider its current performance (by defining more ambitious financial targets in order to clarify the need for change), and then reconsider its action plans. They also want to communicate new strategic requirements (through the planning system) and to make sure that actions are implemented to establish the new strategy (with the diagnostic control system). Reexamining the belief and boundary systems of the organization is not necessary.

In the same perspective, Bruining et al. (2004) show the use of levers of control differs according to the importance of the strategic change. A significant change which is focused on innovation requires the development of a belief system in relation to the newly expected behaviours and attitudes. That also leads to a situation of interactive control in order to build the components of this new strategy and to be reactive when facing new opportunities. Afterwards, diagnostic control is necessary to disseminate new requirements and to generate new practices. In contrast, a less radical strategic change, primarily consisting of revitalizing the company's performance, essentially results in a reinforcement of the existing diagnostic control.

This research confirms the preceding results except for one essential point. According to Simons (1994), interactive control does not intervene in the definition and in the implementation of change. Managers use it only in the second phase (after the first twelve months) to focus the organization's attention on uncertainties related to the new strategy. There is no real co-construction of the project of change by employees, except for strategic 
uncertainties where it is difficult to indicate orientations and their contents. This reinforces the traditional vision of control as a tool for implementing strategic change. This last result may be explained by the type of change: planned and directed whatever its extent (revolutionary or evolutionary), which presupposes the existence of visionary leaders able to impose their desired changes. However, certain papers also suggest the existence of non-directed changes.

\section{Intentionality of change: built versus prescribed change}

A prescribed change is generally planned, and is based on a new vision imposed by managers. The managers set out the orientation and the content of the change that they are proposing, provide explanations and justify the change to employees to obtain their adhesion. In order to induce appropriate behaviours and ensure the implementation of the project, certain targets are imposed on the entire organization (Vandangeon-Derumez, 1998). In its traditional version, control can contribute to the management and control of the implementation of change by standardizing learning and by conforming behaviours.

A built change begins with a rather unclear vision of the future. The project of change is hardly formalized and its contents are not specified by managers. The leader no longer directs change. He is no longer perceived as an omniscient hero, and instead behaves rather like a guide or a facilitator setting up the necessary conditions for the change to emerge from collective action (Palmer and Dunford, 2008). As Armenakis and Harris (2009) suggest, some key beliefs regarding change (for example its supposed efficiency or valence) play an important role in the "three steps of the change process: diagnosis, creating readiness and change adoption". More precisely, the leader seeks to support the development of a dialogue allowing the pooling of knowledge and the confrontation of points of view. This interaction facilitates the modification of the cognitive and behavioural process of employees. Thus, the development of dynamics of built change leads to a reconsideration of the role of management tools from a perspective which is less focused on conformation (framing, normalizing 
behaviours etc.) than exploration (inventing a new collective process of evolution, supporting the emergence of shared representations etc.) (Armenakis et al., 1993; Grimand and Vandangeon-Derumez, 2000). From this point of view, control conceived of as a means of discussion and negotiation can, a priori, be an interesting tool. It can stimulate and frame new ideas and initiatives and thus make the paradigm of the organization evolve.

Prescribed change therefore falls within a more traditional vision of an organization with managers who prescribe and employees who carry out. In reality, two logics coexist within the same process (Vandangeon-Derumez, 1998). With prescribed change, it is often necessary to return to a logic of built change to ensure individual learning and to limit resistance. Conversely, at a certain moment in time, built change requires individual actions to be stabilized. It is then a question of anchoring changes in daily practice by standardizing individual learning, namely by selecting and generalizing new knowledge. Thus, according to the stage of the process of change, control could be both a tool for standardization and conformation (instrumental vision) and a tool for the co-construction of change (interactive vision).

The confrontation of the two abovementioned perspectives (radicality and intentionality) leads to our first matrix (fig. 1).

Figure 1. Typology of control systems with intentionality and radicality of change

According to Simons (cells 1 and 2), interactive control focuses on strategic uncertainties at a comparatively later stage than diagnostic control. The change is implicitly regarded as prescribed. The possibility of co-construction is not considered. On the other hand, the second classification considers that change can be either prescribed or built. The first, considered as somewhat revolutionary (cell 2), would be accompanied by a control system to conform 
behaviours. The second, more evolutionary in nature (cell 3), would result in interactive control facilitating co-construction.

The "built-revolutionary" change (cell 4) is not evoked. The question is whether such a change might be accompanied by:

- A revision of the belief and boundary systems in order to leave the established framework;

and

- Interactive control of non-stabilized elements.

Both prescribed and built change presuppose a change process under control, with the underlying postulate of the rationality of actors and organizations. The change is intentional, planned, and under the control of management. The changes only differ in the details of their implementation, with a more bottom-up, emergent, and iterative learning process being observed for built change. This typology is based on Lewin's three steps, which many scholars consider as a planned approach to change (Weick and Quinn 1999; Burnes 2004; By 2005). This episodic change (infrequent, discontinuous and intentional) is often contrasted with continuous change, which is perceived as an emergent and self-organizing process (Weick and Quinn 1999; By 2005; Nasim and Sushil 2011). It does not take into account changes described as spontaneous (organic) (Mintzberg et al., 1999); in other words, minor changes resulting from local initiatives which are not caused, managed, or controlled by leaders.

Furthermore, this typology does not consider the temporality of change, when in fact the needs of management may vary according to the particular phase of the change process.

\section{Temporality of change}

To account for the sequencing and linearity of change (Amis et al., 2004), the process of change can be summarized as consisting of several distinct phases, the precise details of which vary from one author to another. This does not exclude major arguments on the continuity of change (Stebbings and Braganza, 2009). For example, Vandangeon-Derumez (1998) refers to 
the following three phases: maturation, uprooting and rooting, which are close to the generally accepted phases of Lewin: unfreezing, moving, and refreezing (Lewin, 1951; Goodstein and Burke, 1991; Schein, 1996; Burnes, 2004).

The unfreezing phase is characterized by an awakening of the need for change and by the development of a project of change. The content of this project is then communicated to the organization and implemented (moving phase), before being definitively anchored at the level of daily practices (refreezing phase). However, the roles of the actors and control systems differ depending on the particular phase of the process (Goodstein and Burke, 1991; Grimand and Vandangeon-Derumez, 2000; Walker et al., 2007).

With prescribed change, managers can use control systems for internal and external diagnosis purposes (unfreezing phase). The following stage (moving phase) consists of diffusing and establishing a relatively well-framed and planned project. To control its implementation, "accompaniment of change" type tools are recommended, facilitating the installation of change by conveying a new representation of the organization (Goodstein and Burke, 1991). These authors also recommend using tools to frame behaviours and work practices in order to implement change and control its implementation. In addition, Simons (1994) shows that, in the second phase, it is necessary to use interactive control on the nonstabilized elements related to the uncertainties generated by the new strategy. The anchoring of changes in daily practices (refreezing phase) is designed to reduce the emergent initiatives of actors who often try to appropriate the project and modify it. Thus, to preserve the coherence of the initial framework, the company can use administrative and cultural systems to frame behaviours and to standardize the learning that emerged during the preceding phase, and which is positioned within the framework of the project (Goodstein and Burke, 1991).

A built change results in a weakly formalized project. Leaders expect employees to become aware of the need for change and to mobilize themselves to build the framework and the contents of change (unfreezing phase). To achieve this, the company can use interactive control 
tools to allow people to agree on the problems to be solved and to envisage potential solutions (Grimand and Vandangeon-Derumez, 2000). In the following stage (moving phase), managers wish to support local initiatives by leading employees to gradually build change through their interactions and their individual and collective initiatives. Leaders take part in the process by trying to locate and to select local initiatives likely to improve organizational routines and by stimulating them using ad-hoc coordination devices (Grimand and Vandangeon-Derumez, 2000). In the following stage (refreezing phase), leaders take over the process of change to formalize and impose the new vision and the new organizational framework built locally by all actors. This presupposes stabilizing the situation and normalizing behaviours in order to capitalize on, and to diffuse, new ideas and learning by anchoring behaviours in the organizational field. 
Table 1. Control and temporality of change

\begin{tabular}{|c|c|c|}
\hline $\begin{array}{l}\text { Step of } \\
\text { Change }\end{array}$ & Built Change & Prescribed Change \\
\hline Unfreezing & $\begin{array}{l}\text { Control is regarded as a tool for analysis, } \\
\text { with its potential for organizational } \\
\text { diagnosis and its interactive dimension } \\
\text { allowing actors to analyse the situation of } \\
\text { the firm together. }\end{array}$ & $\begin{array}{l}\text { Control is regarded as a tool for analysis and } \\
\text { organizational diagnosis to help top management } \\
\text { to define change. }\end{array}$ \\
\hline Moving & $\begin{array}{l}\text { An interactive control to explore new } \\
\text { ideas and knowledge together, and to } \\
\text { build change gradually. }\end{array}$ & $\begin{array}{l}\text { A tool for accompanying change. The structure } \\
\text { and contents of control may be adapted to the } \\
\text { new strategic vision and the new organizational } \\
\text { framework. A control system facilitates the } \\
\text { development of new behaviours and logics of } \\
\text { operation. } \\
\text { A tool for conforming behaviours, in order to } \\
\text { implement change and to control its } \\
\text { implementation with more traditional control. } \\
\text { Interactive control focused on strategic } \\
\text { uncertainties }\end{array}$ \\
\hline Refreezing & $\begin{array}{l}\text { Traditional control, a stabilization and } \\
\text { conformation tool used to: } \\
\text { - formalize and impose the framework of } \\
\text { change built by actors; and } \\
\text { - convey the new representation of the } \\
\text { organization and then to facilitate the } \\
\text { adoption and generalization of suitable } \\
\text { behaviours. }\end{array}$ & $\begin{array}{l}\text { Traditional control to frame behaviours and to } \\
\text { standardize learning. }\end{array}$ \\
\hline
\end{tabular}




\section{Methodology}

This article proposes a new examination of the ways in which control systems contribute to the process of change, taking into account the previous typology frameworks. More precisely, it examines the process of change undertaken in the family business succession of the GCB Company. The authors first present the context of the research, and then set out the sources of data used, the data collection procedures, and the method of analysis.

\section{Case study background}

The GCB Company has been operating in the highly concentrated sector of public works for more than fifteen years. Larger companies share the major part of the market and generate a significant proportion of their growth each year by purchasing small firms with a strong local presence. For the most part, activity consists of public-to-private service concession arrangements. The marginal effort made by a small firm to win a contract (for example the contract for cleaning a city's water) is rewarded by seven to twelve years of contractual monopoly. It is therefore tempting for big companies to acquire small firms and allow these acquired firms to retain their management autonomy. Furthermore, this safeguarding offers more leeway in terms of responding to invitations to tender. In reality, when several companies bid, not all of them are able to keep their commitments. So, if a small subsidiary company wins a contract because of its effective local presence, it "subcontracts" the contract to its head office.

In this context, the strategic position of GCB, a family company in the south-west of France, is particularly unusual. The company has a physical presence in several departments, with its head office being based in Bordeaux, and has experienced strong growth over the last seven years. It employs more than 350 people, has a consolidated turnover of 60 million euros and almost no long-term debt. It has succeeded in maintaining profitable activities in five fields: water pipelines, electric lines, telephone lines, collection and treatment of waste and, in 
particular, service activities (construction of water purification plants and water turnkey contracts).

This diversification, which is very unusual for a family company of this size, has enabled it to resist the strongly cyclic nature of public contracts better than other firms. Its local dynamism and its financial performance have made it particularly attractive for large companies. However, its chairman Charles Bixente (pseudonym), 63 years old, always wanted the company to remain independent and even developed an "anti-group" culture. He was supported in this choice by his executive vice president (Rodolf Boscher), despite the company having made three successful acquisitions in the last five years. Charles Bixente subsequently made the decision to hand down his company to Philippe, one of his sons.

In many respects, company successions closely resemble a model of organizational change conforming to the processual framework of "unfreezing - moving - refreezing", but in a different semantic form. Indeed, the stages "preparation - negotiation - integration" (Haspelagh and Jemison, 1987), or "diagnosis - preparation - integration" (Tabrizi, 2007) are broadly developed. Furthermore, the GCB transfer process comprises evolutionary changes, including modification of the hierarchical relations and internal communications of the group. It also includes radical changes to the design of the structure of authority and the negotiated change of power within the system of governance. In other respects, some changes are built like operational practices while others are prescribed, such as the succession between the outgoing chairman and his successor.

\section{Collecting data}

This study was carried out in the GCB Company over a period of 17 months. When a study encompasses a large number of factors of influence and methods of control which overlap in complex ways, it is necessary to focus the analysis on the more significant variables of the issues examined (Otley, 1999). The first stage of data-gathering consisted of interviewing 
managers in charge of subsidiary companies, managers at the n-1 and n-2 levels, and a selection of employees drawn at random from each sector of the firm (table 2).

Table 2. Individuals interviewed

\begin{tabular}{|c|c|c|c|}
\hline Sites & Individuals & Job titles & $\begin{array}{l}\text { Source of information: } \\
\text { interview (A), direct observation } \\
\text { (B), documents (C) }\end{array}$ \\
\hline \multirow[t]{12}{*}{ Parent company } & Charles Bixente & Chairman and CEO & $\mathrm{A}, \mathrm{B}, \mathrm{C}$ \\
\hline & Philippe Bixente (son) & Information Systems & $\mathrm{A}, \mathrm{B}, \mathrm{C}$ \\
\hline & & Director & \\
\hline & Rodolf Boscher & Executive Vice President & $\mathrm{A}, \mathrm{B}, \mathrm{C}$ \\
\hline & Camille L. & Accounting Manager & $\mathrm{A}, \mathrm{C}$ \\
\hline & Frédéric M. & Logistics Manager & $\mathrm{A}, \mathrm{C}$ \\
\hline & Gaston N., Charles O., & Area Manager & $\mathrm{A}, \mathrm{C}$ \\
\hline & Arnaud P., Félix Q. & & \\
\hline & Guillaume R., Paulin S., & Head of Department & $\mathrm{A}, \mathrm{B}, \mathrm{C}$ \\
\hline & Alix T., Marcel U. & & \\
\hline & Rémi V. & Project Manager & $\mathrm{A}, \mathrm{C}$ \\
\hline & Nina W. & Secretary & $\mathrm{A}, \mathrm{C}$ \\
\hline \multirow[t]{2}{*}{ Subsidiary A } & Louis A. & Financial Manager & A \\
\hline & François B. & Project Manager & $\mathrm{A}, \mathrm{C}$ \\
\hline Subsidiary B & Léon D. & Project Manager & $\mathrm{A}, \mathrm{C}$ \\
\hline
\end{tabular}

Several sequences of observations took place, at two-month intervals, in order to identify the changes and the evolution of control perceived by the actors as having become part of the organizational routines and operational procedures.

This first step was necessary to measure the extent to which control instructions were trickling down to the operational levels of the company. It is important to note that key participants were interviewed several times as the hand-down process evolved. The interviews were mostly formal and enabled participants to be observed as they fulfilled their professional 
duties. Some informal information, collected after work hours, gave a sense of how participants confronted change. The interviews aimed to evaluate whether control decisions were an operational reality perceived by the operators, or whether they were merely formal statements made at the strategic level.

To avoid contaminating the relationship with the employees, the authors subsequently collected sensitive information related to time worked, hidden costs and certain items contained in the "social balance sheet" (turn-over of technicians, etc.). The authors focused primarily on the perceptions of the people involved, subsequently corroborating these perceptions with the firm's documents in a second stage. The opposite approach (namely examining the documentary evidence prior to the interviews) would have risked misdirecting the interviews and the investigation towards the deficiencies of the control system in facing the changes experienced by the company.

Finally, the authors collected information relating to the legal structure of the company, namely data on the distribution of shares between shareholders, the company's financial structure, its accounts and its social information over a three-year period, employees' working hours, and the budgetary involvement of each service and subsidiary in the operational process. For the technical services activities, information was gathered regarding the website, production logistics, segment information, contracts with customers and with communication agencies; while data on the flow of information to and from the parent company, and items related to the quality certification were collected from employees from the various departments and subsidiaries.

\section{Analysing data}

The authors made use of the iterative process recommended by Chenhall and Euske (2007), in which collected data is tied to events or participants, allowing participants to comment on the analysis. These comments can be made during formal or informal meetings. 
Some frameworks provide an interesting operational understanding of change. For instance, the TROPICS model presents different parameters of change (Time scales, Resources, Objectives, Perceptions, Interest, Control and Source) (Paton and McCalman, 2008). It provides an interesting operational understanding of change. However, for the present study, the authors have favoured a framework, similar to that of Dambrin et al. (2007), which is more closely related to the actual control systems. According to this framework, an organization's control system can be designed by selecting from a portfolio of control mechanisms, called a control mix. The authors have therefore structured their analysis of the control system during the family succession into four categories:

- Performance measurement model;

- Structure of power and the role of management;

- Relationship with stakeholders; and

- Engineering of the operational process.

Because power and politics intervene in the process of change (Mendelow, 1991; Turner et al., 2002; Gervais and Herriau, 2011), they are considered as levers of control for the following two categories: structure of power and the role of management, and relationship with stakeholders. Furthermore, to obtain a better understanding of the management of change with the aid of the control system, the authors have also chosen to include the more traditional control mechanisms related to the performance measurement model and the engineering of the operational process.

Table 3 presents the framework used to analyse the links between a control system and the three stages of the transfer (unfreezing, moving, refreezing). 
Table 3 - Analytical framework

\begin{tabular}{lccccc}
\hline \multirow{2}{*}{$\begin{array}{c}\text { Radicality of } \\
\text { change }\end{array}$} & Intentionality of & & \multicolumn{2}{c}{ Control mix } \\
\cline { 3 - 6 } & change & Performance & Structure of & Stakeholders & Operational \\
& & measurement & power & & process \\
\hline Revolutionary & Built (1) & A1 & B1 & C1 & D1 \\
& Prescribed (2) & A2 & B2 & C2 & D3 \\
\hline Evolutionary & Built (3) & A3 & B3 & C3 & C4 \\
\hline
\end{tabular}

For each of these categories, it was possible to observe the change: its radicality, its intentionality and its temporality. In parallel, the control levers used in each phase were listed. For example, if a transition from "evolutionary-built" to "revolutionary-built" change was observed during the transfer, the corresponding transition from position 3 to position 1 was then analyzed for each category (A to D) of the control mix.

\section{Results}

This section presents the results for the phases of unfreezing, moving and refreezing.

The unfreezing of the transfer: from "evolutionary - built" to "revolutionary - built" change The unfreezing phase of the family succession was characterized by the transition from an "evolutionary-built" phase, where the transfer was open to discussion, to a "revolutionarybuilt" phase, which was more abrupt.

With the transfer of GCB, conflicting opinions appeared concerning two contradictory requirements. On the one hand, Charles Bixente wanted to make the transfer without clearly evaluating the operational implications of his decision, without being sure, for example, of the legal form of his decision and without precisely imagining his role after the transfer. He did not wish to be abrupt with his staff but, as far as possible, wanted a process shared by all 
employees with an evolutionary and built change. On the other hand, his son Philippe brought up the issue of time constraint. According to Philippe, symbolically, the transfer had to be performed as quickly as possible in order to limit "pollution" of the head office, which could have been perceived as indecisive. In his opinion, the change needed to be more revolutionary.

In fact, the family business succession started with an evolutionary and built change with the development of two categories of tools which aimed to measure the effects of the transfer: - Working groups were set up to assess the firm's ability to evolve. The actors were supposed to put forward ideas for general improvements in their company without being made aware of the reasons behind the work. In fact, what the three key executives, Charles Bixente, Philippe Bixente, and Rodolf Boscher, actually wanted to know was how much leeway they had to implement the change, and what their levers were. They also expected to identify potential budgetary slack.

- A debate between these three key executives was officially launched concerning the quality process, the performance of the subsidiaries, and the patrimonial state of the firm via a largely interactive and concerted exchange. The goal was to lay down the operating rules of the transfer process and the roles of each person.

The actors were not fooled by their requirement to participate in this thinking process. They understood that a "bridge would be crossed". In spite of the presence of Philippe Bixente, who had been with the company for two years, working with the chairman as information systems director, some managers thought that they would "be sold to a group", because no successor or transferee had been appointed. The participants thought that the business objectives and the methods of evaluating individual performance would change and become more financially oriented.

In terms of the structure of power, the father and son worked together to determine how the father could best transfer power to his son, whereas the real problem was actually how to move from the existing dual management structure (Charles Bixente - Rodolf Boscher), to a different 
dual management structure with more technically recomposed roles (Philippe Bixente - Rodolf Boscher), after a two- or three-year tricephalous phase (Father - Son - Rodolf Boscher). The concerns of management flow charts and power struggles between subsidiary companies also quickly emerged, with Rodolf Boscher being very present in the commercial aspects of all of the subsidiary companies. The future governance would not resemble that of Charles Bixente for three reasons. Firstly, the chairman did not specifically wish to favour Philippe compared to his other children. Even if Philippe had majority voting rights, he would not own the entire capital, in contrast to his father's situation. Secondly, the father did not know what his role would be after the transfer and whether he would still be a company shareholder or not. Thirdly, on Rodolf Boscher's appointment, it had been agreed that he would ultimately be appointed as an associate, rather than merely remaining the executive vice president. After two months, it became evident that the initial ground work had been ineffective. Rumours began to circulate, some tensions appeared, the transfer date was not set, and the management flow chart had not been completed. Some unforeseen changes occurred, with the departure of four important managers. Furthermore, after the annual summer holidays, the top executives had little time to discuss and synthesize the contributions of the working groups.

A "fortuitous" event which had a catalytic effect on the change process highlights the fact that the control tools that were meant to enable a co-construction of change were, in fact, ineffective. However, they did result in the process converging towards a better-controlled "revolutionary-built" stage. After a building site was significantly damaged, an event which could have been seriously prejudicial to the profitability of the company, Charles Bixente gathered all of his managers for a general meeting. While discussing the future of this important building site, he unexpectedly raised the issue of the company's future and his plans to hand down control to his son Philippe. Answering the questions arising from this surprise announcement gave him the opportunity to announce that further information would be 
presented in January, and that the working groups that had been in place since June would develop proposals for the family transfer.

Table 4 presents a summary of the main elements of the unfreezing phase.

Table 4. Exploring the unfreezing phase

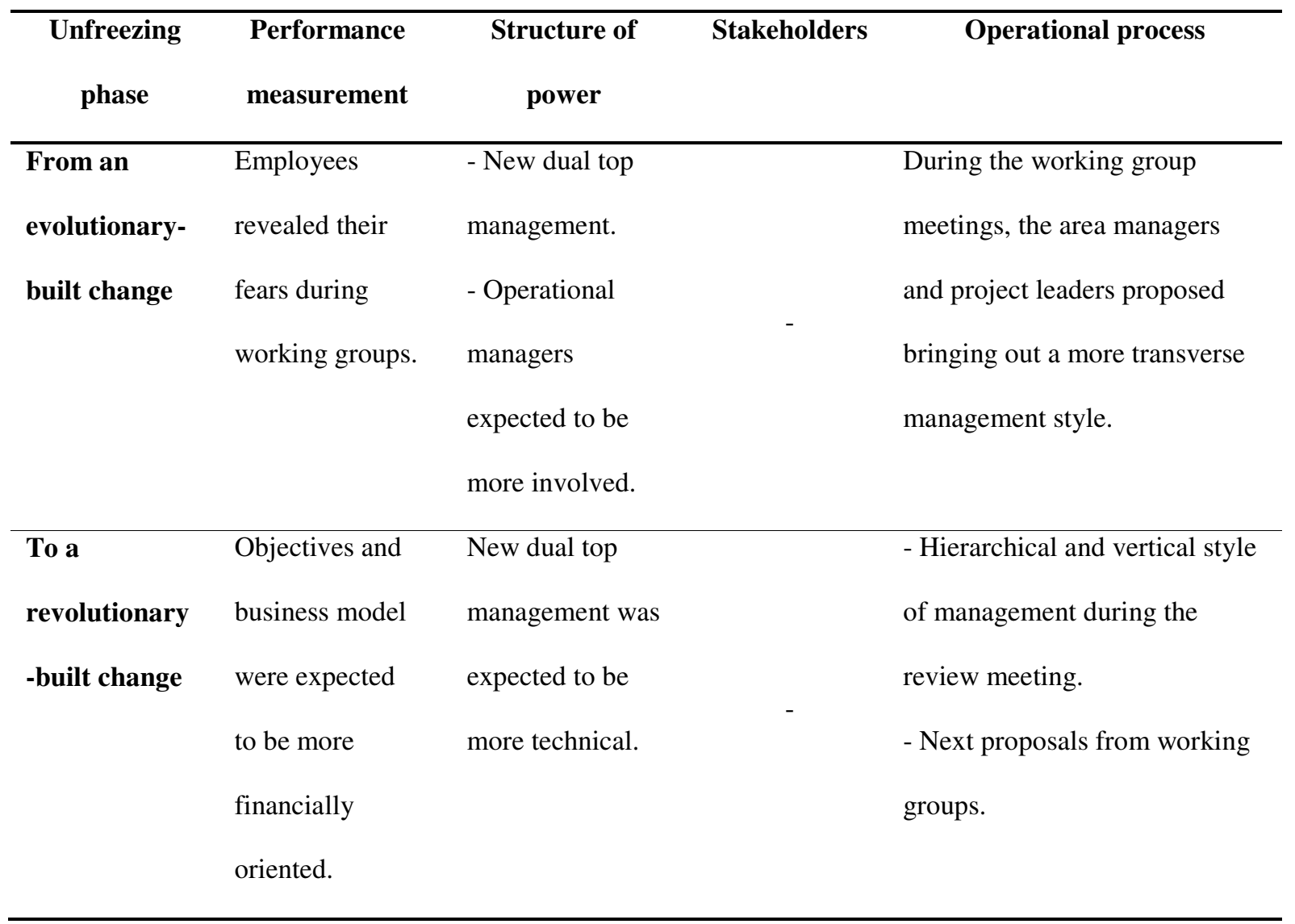

Thus, during the unfreezing phase, the change was somewhat built, with an interactive use of levers of control to analyse the situation and to define the details of the transfer. At the end of this first step, the change became more revolutionary with the announcement of the family business succession.

The moving phase: towards "evolutionary - prescribed" change

The moving phase, which lasted until the beginning of the following summer, was shaped in a different way. In addition, the emerging tools used to control the change moved in a more prescriptive way than initially desired by the chairman. 
Charles Bixente and the accounting manager dealt with budgets while Rodolf Boscher was the real driving force behind the network of commercial relations with local government agencies. They were assisted by the staff in charge of subsidiary companies, all of them former in-house-trained site foremen. The January announcement consolidated Philippe Bixente by positioning him as executive vice president in charge of operations. The role of Rodolf Boscher was also clarified as executive vice president in charge of commercial relationships. The difficulty was how to allow the current chairman to gradually withdraw from his areas of responsibility while leaving a profitable legitimacy to his son. In this context, Philippe Bixente's management of his dual initiatives of launching quality certification procedures and reorganizing internal databases positioned him in the company as a future chairman with responsibility for company projects, meaning that he was not merely considered to be a simple heir. He handled the recruitment of the people charged with supporting him, much as his father had done when he personally recruited building site foremen in order to maintain a strong personal bond. Change became increasingly prescribed in order to pacify the reactions of senior executives to the fast nomination of the son. The quality certification requirement was perceived by these managers as a cumbersome process which was not appropriate for their practical culture. On the other hand, the working groups allowed junior managers, who were more highly educated and more mobile, to dissociate themselves from their directors and to escape their supervision.

With the concentration of the sector, the company needed to react to the innovative methods implemented by its competitors (trenchless building sites, drain replacement by bursting, for example). It also had a five-year window in which to address a new key factor for success in the sector: access to the recruitment of qualified staff. Wanting as far as possible to bring the site foremen into the thinking process, Philippe Bixente asked them to think about a taskcompetence matrix within their activity and to make proposals. This required pointing out, through "impartial" tools, that some employee profiles were no longer adapted to the practices 
of customers who were better trained, more technical and very sensitive to legal risks. A new employee profile, rarely sought by competitors, gradually emerged: agriculture school graduates, highly trained in management and in outdoor work. It also revealed the maladjustment of the old technical-commercial managers and a strong imbalance of the population pyramid which may well result in the departure of the majority of the executives within a seven-year horizon.

Furthermore, to impose his views on subsidiary managers, Philippe Bixente gradually appropriated and automated the forecasting and control tools by developing a computerized information system. Nevertheless, for a certain time, budgeting remained the prerogative of the outgoing chairman enabling him to meet, each year, all subsidiary executives. He performed this ritual round alone, never asking his son to accompany him.

Table 5 presents a summary of main elements of the moving phase.

Table 5. Exploring the moving phase

\begin{tabular}{lllll}
\hline \multicolumn{1}{c}{ Moving } & Performance & Structure of power & Stakeholders & Operational process \\
phase & measurement & & & \\
\hline Towards an & Appropriation and & - Two executive vice & Updated practices & - Development of new \\
evolutionary & automation of & presidents in charge of & employed by public & control tools imposed \\
-prescribed & forecasting and & operations and commercial & customers imposed & by Philippe. \\
change & control tools by & relationships, respectively. & new commercial & - The youngest \\
& Philippe Bixente. & - A new structure of & habits. A new profile & executives developed a \\
& & competencies emerged & of technical staff & genuine ability to \\
& & through the progressive use & therefore needed to be & employ innovative \\
& & of a computerized & recruited. & processes and tools.
\end{tabular}

The change was somewhat evolutionary but, overall, more prescribed. Philippe Bixente automated the process control and developed new tools to force the change and to facilitate the development of new behaviours and logics of operation. 
The refreezing phase: towards "revolutionary - prescribed" change

Observations covered only the beginning of the refreezing phase. This phase faced several organizational challenges. In an environment of negotiation where significant developments had been experienced in recent years (regrouping of towns, higher technicality of interlocutors etc.), more formalized commercial relations had to be considered. However, the commercial organisation and control structure relied heavily on the individual implication of actors and remained rather informal. It was therefore difficult to control without strong inter-individual experience. Accordingly, Philippe recruited a specialist in information systems to carry out an audit of the various subsidiary companies, the most autonomous in particular. It became clear that the goal was to achieve homogeneous behaviours and work practices, especially in the small units where the culture of writing reports with paper and pen remained strong. While Philippe Bixente did not benefit from the strong relations with the executives that his father had enjoyed, he sought to depersonalize and to centralize control by making it increasingly formalized, by marking his different style and thus pushing out some of the less enthusiastic "old managers", and by changing the control references.

The marketing repositioning marked an internal change visible in three key elements of communication. The senior managers of all subsidiary companies have successively announced changes to their subsidiary's logo and website, and a revamping of all sales brochures. Within this framework, the recasting of the business and the final amendments to the management flow chart have focused on the concept of networks (cleansing network, etc.), marking Philippe Bixente's preference for developing innovative public works technologies, as evidenced by the new commercial brochure that he designed. In fact, he has attempted to be more independent, moving away from the commercial influence of Rodolf Boscher. With this aim in mind, he has set up tools to analyze the business performance of subsidiaries. This has led to a change in the behaviour of participants. For example, area managers now send their reports to Rodolf 
Boscher and give a copy to Philippe Bixente. In addition, they are more at ease when discussing their reports with Philippe Bixente than they were prior to the company's reorganization.

Table 6 presents a summary of the main elements of the refreezing phase

Table 6. Exploring the refreezing phase

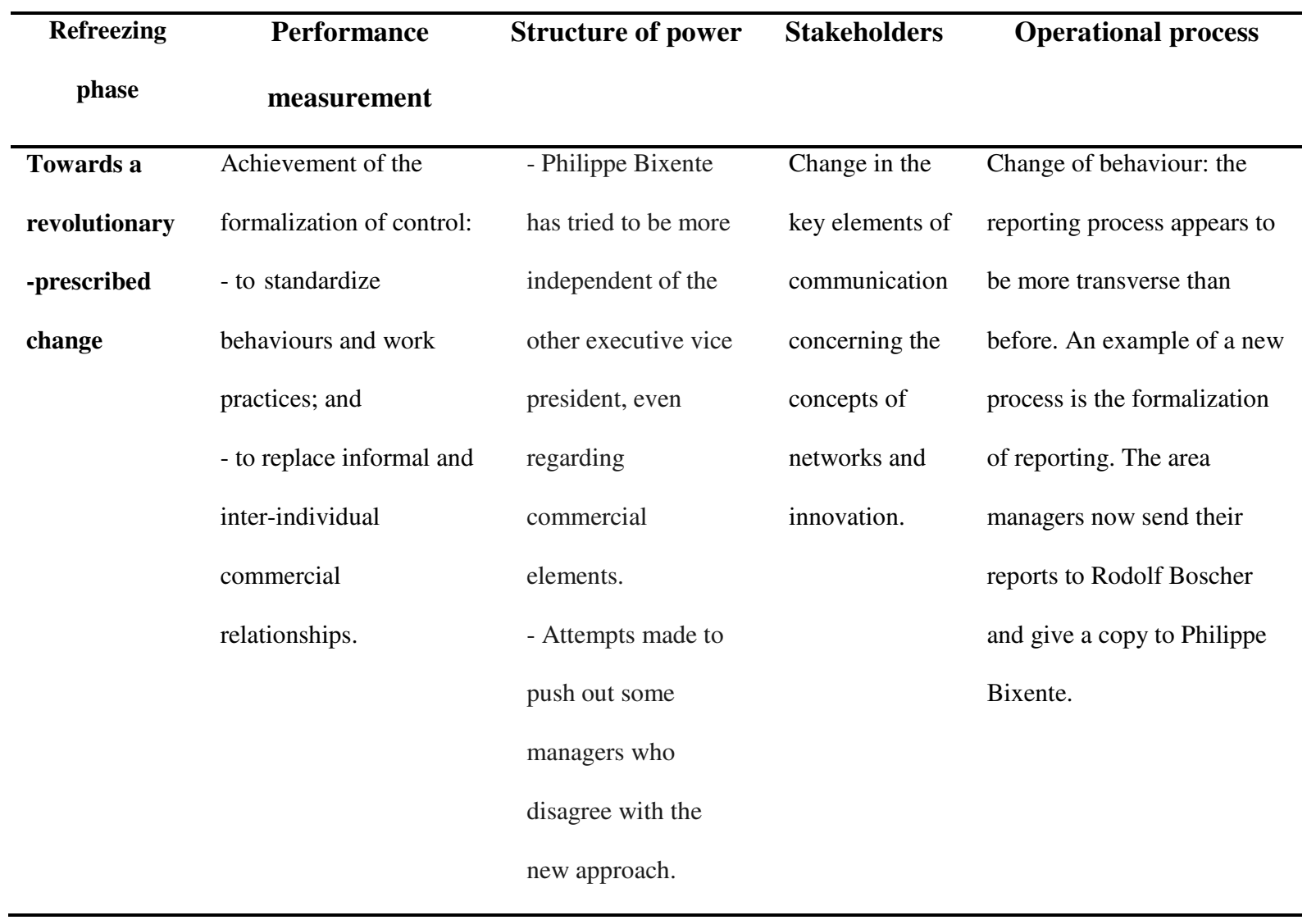

During this last phase, the change remained prescribed but was more revolutionary. Philippe Bixente completed the process of formalizing and centralizing control in order to impose his authority and to frame the behaviours and processes for the strategic framework that he has defined.

The various different projects have not advanced at the same rhythm, which has introduced complexity and reduced the clarity of the whole scheme. Nevertheless, it is possible to combine the theoretical grid and table (figure 1 and table 1) to illustrate the specific changes related to the transfer of GCB (figure 2). 
Figure 2. Summary of results: process of change and mode of control

\section{Discussion}

This case study confirms and supplements the conceptual framework developed by the authors. It illustrates the links likely to exist between the various phases of change, its evolutionary or revolutionary aspects, and the mode of control.

The conceptual framework employed in this article gives rise to several comments and questions. First of all, the developments are based on the assumption that change constitutes an intermediate phase between two periods of stability, which excludes the possibility of the adaptation or permanent evolution of companies (Weick and Quinn, 1999). The management of change relates less to controlling the implementation of change and increasingly to managing the capacities for change (Meyer and Stensaker 2006), with the management of the organization's capacities to continuously renew its routines through learning. This is observed in the refreezing phase of $\mathrm{GCB}$, where the quality process implemented has continued beyond the transition. This situation testifies to the company's continuous adaptation. The role of top management does not solely consist of controlling change, they must also create a favourable context for the establishment of continuous change and its diffusion (Weick and Quinn, 1999; By, 2005). Lastly, the selected process of change is based on Lewin's framework, which is often criticized for its linear, sequential, static and planned nature (Nasim and Sushil, 2011; Sillince, 1999; Weick and Quinn, 1999). Despite these criticisms, it remains widely used and is regarded as completely up to date (Goodstein and Burke, 1991; Schein, 1996; Burnes, 2004).

Lastly, the present results raise several questions about the functionalist posture of control adopted in this article. They over-estimate the rationality of control and its actors, and underestimate the force of institutions, social conventions between actors, their ways of thinking, organizational routines and political games which nourish and support these tools, and also the aptitudes and commitments of individuals regarding change. 


\section{Conclusion}

The aim of this article was to reconsider the role of control in a dynamic of change using the case study of a family business succession. The authors' objective was to fill a gap in the change and family business succession literatures by seeking to gain a better understanding of the connections between change and control tools. The study questioned the extent to which control can contribute to the management and control of change, particularly in family-owned business successions. This required combining the results of two different disciplinary fields, namely the control system and organizational fields of research.

Despite the previous limitations, this research shows that control is able to structure change by inducing suitable behaviours. Control systems are not only used to set up the organizational evolution previously decided upon by managers; nor are they limited to stabilizing and conforming behaviours in order to implement change and control its implementation. Control tools can in fact also be used to convey the desired change by building a new representation of the organization in order to facilitate the development of new behaviours and logics of action. Furthermore, they can become tools used by all employees to manage and build change by stimulating and framing employees' initiatives and experiments, which are themselves sources of learning and new knowledge.

There is a dynamic interaction between control systems and change. The levers of control can vary according to the radicality of change (evolutionary - revolutionary), its intentionality (built - prescribed) and its temporality (unfreezing, moving, refreezing). This article proposes an analytical and operational framework linking the characteristics of change and the control tools.

By applying the model to the case study of a father-to-son company succession, the article shows that control systems can help to structure the process of change in a family business 
succession. It also confirms the importance of the individual factors (successor- and incumbent-related factors) and relationship factors (relationships with/between family and nonfamily members) seen in family business succession literature. These factors affect the structuring of the control system and the ability of the managers to propose tools of control. Furthermore, the way in which managers use the control tools to manage the change can be a key factor in the success or failure of the succession process. This is one more key factor to take into account in theories of family business successions.

The framework developed in this article can be used as a basis for future research on change and control. Nevertheless, it needs to be confirmed, particularly with other research relating to organizations going through a different type of change. The tools and levers of control may be used differently. It could also be interesting to widen the field of investigation to continuous change (Weick and Quinn, 1999), introducing specific and critical aspects of "the morphing type of transformation” (Marshak, 2004).

Finally, beyond this dynamic perspective on control and change, we open the debate on the understanding of how individual and organizational learning, necessary in situations of change, can be initiated and tallied with control systems which are not only used in an exclusively instrumental way, but which are also useful from an interactionist perspective.

\section{References}

Abernethy, M.A. and Brownell, P. (1999) The Role of Budgets in Organizations Facing Strategic Change: An Exploratory Study, Accounting, Organizations and Society, 24(3), pp. 189-204.

Amis, J., Slack, T. and Hinings, C.R. (2004) The Pace, Sequence, and Linearity of Radical Change, Academy of Management Journal, 47(1), pp. 15-39.

Armenakis, A.A., Harris, S.G. and Mossholder, K.W. (1993) Creating Readiness for Organizational Change, Human relations, 46(6), pp. 1-23.

Armenakis, A.A., Harris, S.G. (2009) Reflections: Our Journey in Organizational Change research and Practice, Journal of Change Management, 9(2), pp. 127-142. 
Berry A.J., Coad A.F., Harris E.P., Otley D.T. and Stringer C. (2009) Emerging Themes in Management Control: A Review of Recent Literature, The British Accounting Review, 41, pp. 2-20

Bisbe, J. and Otley, D. (2004) The Effects of the Interactive Use of Management Control Systems on Product Innovation, Accounting, Organizations and Society, 29(8), pp. 709-737.

Bruining, H., Bonnet, M. and Wright, M. (2004) Management Control Systems and Strategy Change in Buyouts, Management Accounting Research, 15(1), pp. 155-177.

Burns, J. and Vaivio, J. (2001) Management Accounting Change, Management Accounting Research, 12(4), pp. $389-402$.

Burnes, B. (2004) Kurt-Lewin and the Planned Approach to Change: A Re-appraisal, Journal of Management Studies, 41(6), pp. 977-1002.

By, R.T, Burnes, B. and Oswick, C. (2011) Change Management: The Road Ahead, Journal of Change Management, 11(1), pp. 1-6.

By, R.T. (2005) Organisational Change Management: A Critical Review, Journal of Change Management, 5(4), pp. $369-380$.

Chenhall, R.H. and Euske, K.J. (2007) The Role of Management Control Systems in Planned Organizational Change: An Analysis of Two Organizations, Accounting, Organizations and Society, 32(7), pp. 601-637.

Dambrin, C., Lambert, C. and Sponem, S. (2007) Control and Change-Analysing the Process of Institutionalisation, Management Accounting Research, 18, pp. 172-208.

De Massis, A., Chua, J.H. and Chrisman, J.J. (2008) Factors Preventing Intra-Family Succession, Family Business Review, 21(2), pp. 183-199.

Dent, J.F. (1990) Strategy, Organization and Control: Some Possibilities for Accounting Research, Accounting, Organizations and Society, 15(1-2), pp. 3-25.

Ezzamel, M., Lilley, S. and Willmott, H. (2004) Accounting Representation and the Road to Commercial Salvation, Accounting, Organizations and Society, 29(8), pp. 783-813.

Ferreira, A. and Otley, D. (2009) The Design and Use of Performance Management Systems: An Extended Framework for Analysis, Management Accounting Research, 20, pp. 263-282.

Ford, M.W. and Greer, B.M. (2005) The Relationship between Management Control System Usage and Planned Change Achievement: An Exploratory Study, Journal of Change Management, 5(1), pp. 29-46.

Gervais, M. and Herriau, C. (2011) Stratégie de l'entreprise (Paris: Economica, 6th edition).

Greenwood, R. and Hinings, C.R. (1988) Organizational Design Types, Tracks and the Dynamics of Strategic Change, Organizations studies, 9, pp. 293-316. 
Goodstein, L.D. and Burke, W.W. (1991) Creating Successful Organization Change, Organizational Dynamics, 19(4), pp. 5-17.

Grimand, A. and Vandangeon-Derumez, I. (2000) Le rôle des acteurs et des dispositifs de gestion dans la construction des apprentissages stratégiques, XI AIMS congress.

Haspelagh, P.C. and Jemison, D.B. (1987) Acquisitions: Myths and Reality, Sloan Management Review, 28(2), pp. 53-58.

Heracleaous, L. and Barrett, M. (2001) Organizational Change as Discourse: Communicative Actions and deep Structures in the Context of Information Technology Implementation, Academy of Management Journal, 44, pp. $755-778$.

Hughes, M. (2007) The Tools and Techniques of Change Management, Journal of Change Management, 7(1), pp. 37-49.

Jarrett, M. (2008) The new Change Equation, Business Strategy Review, Winter, pp. 76-80.

Kloot, L. (1997) Organizational Learning and Management Control Systems: Responding to Environmental Change, Management Accounting Research, 8, pp. 47-73.

Kober, R., Ng, J. and Paul, B.J. (2007) The Interrelationship between Management Control Mechanisms and Strategy, Management Accounting Research, 18 (4), pp. 425-452.

Langfield-Smith, K. (1997) Management Control Systems and Strategy: A Critical Review, Accounting, Organizations and Society, 22(2), pp. 207-232.

Lewin, K. (1951) Field Theory in Social Science (New York: Harper and Row).

Marshak, R.J. (2004) Morphing: The leading Edge of Organizational Change in the twenty-first Century, Organization Development Journal, 22(3), pp. 8-21.

Mendelow, A. (1991) Stakeholders Mapping, the 2nd International Conference on Information System, Cambridge MA.

Meyer, C.B. and Stensaker, I.G. (2006) Developing Capacity for Change, Journal of Change Management, 6(2), pp. 217-231.

Miller, D. (1993) The Architecture of Simplicity, Academy of Management Review, 18(1), pp. 116-138.

Miller, D., Steier, L. and Lebreton-Miller, I. (2003) Lost in Time: Intergenerational Succession, Change, and Failure in Family Business, Journal of Business Venturing, 18(4), pp. 513-31

Mintzberg, H., Ahlstrand, B. and Lampel, J. (1999) Transformer l'entreprise, Gestion, 24(3), pp. 122-130.

Naranjo-Gil, D. and Hartmann, F. (2007) Management Accounting Systems, Top Management Team Heterogeneity and Strategic Change, Accounting, Organizations and Society, 32(7-8), pp. 735-756. 
Nasim, S. and Sushil (2011) Revisiting Organizational Change: Exploring the Paradox of Managing Continuity and Change, Journal of Change Management, 11(2), pp. 185-206.

Nelson, R.R. and Winter, S.G. (1982) An Evolutionary Theory of Economic Change (Harvard University Press).

Ogden, S. and Anderson, F. (1999) The Role of Accounting in Organisational Change: Promoting Performance Improvements in the Privatised UK Water Industry, Critical Perspectives on Accounting, 10, pp. 91-124.

Otley, D. (2001) Extending the Boundaries of Management Accounting Research: Developing Systems for Performance Management. The British Accounting Review, 33, pp. 243-261.

Otley, D. (1999) Performance Management: a Framework for Management Control Systems Research, Management Accounting Research, 10, pp. 363-382.

Palmer, I. and Dunford, R. (2008) Organizational Change and the Importance of Embedded Assumptions, British Journal of Management, 19, pp. 20-32.

Paton, R.A and McCalman, J. (2008) Change Management - A Guide to Effective Implementation (Sage).

Pettigrew, A.M., Woodman, R.W. and Cameron, K.S. (2001) Studying Organizational Change and Development: Challenges for Future Research, Academy of Management Journal, 44(4), pp. 697-713.

Royer, S., Simons, R., Boyd, B. and Rafferty, A. (2008) Promoting Family: A Contingency Model of Family Business Succession, Family Business Review, 21(1), pp. 15-30.

Schein, E.H. (1996) Kurt Lewin's Change Theory in the Field and in the Classroom: Notes toward a Model of Managed Learning, Systemic Practice and Action Research, 9(1), pp. 27-47.

Shields, M.D. (1997) Research in Management Accounting by North Americans in the 1990s, Journal of Management Accounting Research, 9, pp. 3-61.

Sillince, J.A.A. (1999) The Role of Political Language Forms and Language Coherence in the Organizational Change Process, Organization Studies, 20(3), pp. 485-518.

Simons, R. (1994) How Top Managers Use Control Systems as Levers of Strategic Renewal, Strategic Management Journal, 15(3), pp. 169-189.

Simons, R. (1995) Levers of Control: How Managers Use Innovative Control Systems to Drive Strategic Renewal (Boston: Harvard Business School Press).

Stebbings, H. and Braganza, A. (2009) Exploring continuous Organizational Transformation: Morphing through Network Interdependance, Journal of Change Management, 9(1), pp. 27-48.

Tabrizi, B. (2007) Rapid transformation (Boston: Harvard University Press).

Turner, J.R., Kristoffer, V. and Thurloway, L. (2002) The Project Manager as Change Agent (London: McGrawHill). 
Vandangeon-Derumez, I. (1998) La dynamique des processus de changement, Revue Française de Gestion, 120, pp. 120-138.

Walker, H. Armenakis, A.A. and Berneth, J. (2007) Integrating Change Content, Context, Process and Individual Differences, Journal of Organizational Change Management, 20(6), pp. 761-773.

Weick, K.E. and Quinn, R.E. (1999) Organizational Change and Development, Annual Review of Psychology, 50(1), pp. 361-386. 